\title{
PATHOGENESIS OF CORONAVIRUS-INDUCED INFECTIONS
}

\section{Review of Pathological and Immunological Aspects}

\author{
S. Perlman \\ Department of Pediatrics and Microbiology and Interdisciplinary Program in \\ Immunology \\ University of Iowa \\ Iowa City, Iowa 52242
}

\section{ABSTRACT: MODELS OF CORONAVIRUS PATHOGENESIS}

Coronaviruses and arteriviruses infect multiple species of mammals, including humans, causing diseases that range from encephalitis to enteritis. Several of these viruses infect domestic animals and cause significant morbidity and mortality, leading to major economic losses. In this category are included such pathogens as transmissible gastroenteritis virus, porcine respiratory and reproductive virus and infectious bronchitis virus. The feline coronaviruses (FECV) generally do not cause infections with high morbidity but in a small percentage of cases, the virus mutates to become more virulent. This virus, feline infectious peritonitis virus (FIPV), causes severe disease in young cats. This disease is in large part immunopathological and understanding it is a major goal of coronavirus research.

\section{INTRODUCTION TO MHV-INDUCED NEUROLOGICAL DISEASE}

The most commonly studied coronavirus is mouse hepatitis virus (MHV), in part because the natural host for this infection, the mouse, is more easily managed in the laboratory. Although, as illustrated throughout this symposium, much progress has been made in understanding the pathogenesis of the infections described above, this review will concentrate on MHV and in particular, the neurotropic strains of this virus. The first strain of mouse hepatitis virus was isolated in 1947 from a paralyzed mouse in a colony of Swiss 
white mice at Harvard Medical School (Cheever, et al., 1949). This virus initially caused hindlimb paralysis, but on repeated passage through mice, more virulent variants, which predominantly caused encephalitis were selected. This virus was named the JHM virus (JHMV) and subsequently shown to be a coronavirus, related to other MHV strains. The infection caused by this virus was not extensively investigated until Weiner described a study in which JHMV-induced demyelination was analyzed (Weiner, 1973).

JMHV is now used in many laboratories to study virus-induced neurological diseases, particularly demyelination, and in all cases, these viruses were derived from the virus originally isolated in 1947. Both mice, the natural host for this virus and rats, a species not naturally susceptible to MHV but which can be infected after intracerebral inoculation, are used. In both species, a hallmark of the infection is persistence in nearly all rodents that survive the acute infection. The JHMV used in different laboratories are not identical, however, as changes have occurred in the genome during the course of propagation at different geographical locales. In addition, different strains of mice and rats display different susceptibilities to infection with JMHV. This difference was most apparent in adult SJL mice, a strain that is resistant to JHMV (Stohlman and Frelinger, 1978). This resistance was later used to isolate the host cell receptor used by JHMV to infect susceptible cells (Williams, et al., 1991).

Other factors, such as route of inoculation and age of the host at the time of inoculation also affect disease manifestation and outcome. For example, after intracerebral inoculation with relatively large volumes of virus, JHMV spreads via neurons, the cerebrospinal fluid and even the blood. For the closely related and mildly neurotropic A59 strain of MHV (MHV-A59) intracerebral inoculation results in a hepatitis that may be severe enough to cause death (Lavi, et al., 1986). Delivery of the virus by this route also compromises the blood-brain barrier and this might affect the ultimate disease outcome. On the otherr hand, intranasal inoculation results in a CNS infection in which virus spreads only transneuronally within the CNS (Lavi, et al., 1988; Barnett and Perlman, 1993) but in which the initial process of inoculation may lead to an infection of the respiratory tract, resulting in pneumonia. These studies on route of inoculation also show that unless virus is injected directly into the brain, JHMV (and probably MHV-A59) enters the central nervous system (CNS) only via the olfactory nerve. Even after intraperitoneal inoculation in suckling mice, the pattern of virus spread within the brain is consistent with spread from the olfactory nerve (unpublished observations).

Further complicating studies using JHMV is the high rate of virus variation that arises during the course of an infection. Variability occurs as a consequence of the high error rate of the coronavirus polymerase, common to the polymerases of all RNA viruses since they lack proofreading ability and also as a consequence of the high recombination rate exhibited by all coronaviruses. The RNA molecules within a single cell are not identical but consist of a group of quasispecies. This distribution of similar, but not identical viruses, facilitates virus selection and allows the virus to adapt more readily to changes in the environment. These adaptive qualities of JHMV has been illustrated in several recent sets of studies (e.g., Chen and Baric, 1996).

\section{MURINE MODELS OF MHV-INDUCED DEMYELINATION}

As described above, the strain of JHMV that arose after many passages through the brains of susceptible mice was virulent and caused a high mortality. Demyelination was observed in a few survivors and since the pathogenesis of this process was deemed most interesting, efforts were made to increase the number of surviving mice with demyelination. The 
first approach was to isolate JHMV mutants that caused less encephalitis and more demyelination. The great variability exhibited by JHMV made this process relatively straightforward and several mutants were isolated that were attenuated in their ability to infect neurons (and thus caused less encephalitis) but continued to infect glial cells, resulting in the same amount or more demyelination. These mutant viruses include temperature-sensitive mutants, variants isolated from the original suckling mouse brain pool, monoclonal antibodyresistant variants and variants with deletions in the hypervariable region of the $\mathrm{S}$ protein (Haspel, et al., 1978; Stohlman, et al., 1982; Dalziel, et al., 1986). Some of these variants preferentially appeared to infect astrocytes or oligodendrocytes, resulting in different levels of persistence and demyelination. A second approach was to use virulent virus, but protect neurons from an acute infection by passive infusion of neutralizing antibodies or $\mathrm{T}$ cells (Buchmeier, et al., 1984; Stohlman, et al., 1986; Yamaguchi, et al., 1991). Under these conditions, the virus persisted in the white matter and was able to cause demyelination. In all of these models, mice are sickest at early times post inoculation (p.i.) and if they survive the acute infection, they recover clinically. Consistent with these clinical observations, infectious virus usually can not be cultured after 15-21 days p.i., but viral antigen or RNA can be detected, sometimes only using very sensitive methods such as PCR.

In one model, hindlimb paralysis develops several weeks after inoculation and infectious virus can be consistently isolated from these mice (Perlman, et al., 1987). In this case, suckling C57B1/6 mice are inoculated intranasally with a virulent strain of JHMV. They are protected from acute encephalitis by nursing by dams previously immunized with live MHV-JHM. A variable fraction (40-90\%) develop hindlimb paralysis with histological evidence of demyelination 3-8 weeks after inoculation. When suckling BALB/c mice are inoculated under similar conditions, they are protected from acute encephalitis but do not develop hindlimb paralysis at later times. This murine model differs from the ones described above in that mice remain well until they develop symptoms a few weeks after inoculation and in that infectious virus can be isolated. A recent set of experiments provided an explanation for some of these results (Pewe, et al., 1996). The CD8 T cell response is critical for clearance in most noncytopathic viral infections and although JHMV behaves as a lytic virus in tissue culture cells, in vivo it does not appear to be cytopathic in some cell types. As described below, the target epitopes for anti-MHV CD8 T cells has been identified in BALB/c and C57Bl/6 mice. In each strain, one epitope is dominant and in the case of $\mathrm{C} 57 \mathrm{Bl} / 6$ mice, this epitope is located in a region of the $\mathrm{S}$ protein previously shown to be hypervariable (Parker, et al., 1989). When the virus isolated from the CNS of $\mathrm{C} 57 \mathrm{Bl} / 6$ mice with hindlimb paralysis is sequenced, mutations are detected in every case in this CD8 $\mathrm{T}$ cell epitope. These changes abrogate recognition by CNS-derived lymphocytes in direct ex vivo cytotoxicity assays and thus behave like CTL escape mutants. Since these changes arise early during the infectious process, they are likely to contribute to the initiation of the process of persistence in this strain of mouse.

\section{INFECTION OF RATS WITH JHMV}

Although rats are not a natural host for JHMV, young rats can be infected if virus is delivered by intracerebral inoculation (Sorensen, et al., 1980; Watanabe, et al., 1987). In some strains, a fraction of these mice later develop subacute demyelinating encephalomyelitis (SDE) with clinical signs of paralysis. Several features of this model are unique. First, ongoing demyelination is detected in the presence of minimal amounts of viral antigen in Lewis rats. This is consistent with a previous report showing that $\mathrm{T}$ cells harvested 
from rats with SDE are able to cause neuropathological abnormalities after adoptive transfer into naive mice (Watanabe, et al., 1983). Second, other strains of rats inoculated with JHMV also develop SDE and in some cases, infectious virus can be isolated from symptomatic, but not asymptomatic animals. This ability to isolate infectious virus is the same as described above for the maternal antibody protection model.

\section{SITES OF PERSISTENCE}

Much of the experimental data obtained thus far suggest that the host's ability to clear MHV is a key step in the development of demyelination. Almost invariably, if an immunologically intact host is unable to clear the virus, demyelination results. Virus persistence is known to occur in the white matter of the spinal cord and brain although the molecular basis of this persistence is not understood. Virus can be identified in astrocytes in asymptomatic mice suggesting that this cell type serves as a reservoir in MHV-infected mice (Perlman and Ries, 1987). It is not known if microglia or oligodendrocytes can also serve as reservoirs for virus in asymptomatic mice. It will be particularly fruitful to investigate the role of microglia in this process. Identification of microglia is straightforward since good cell markers are available and there is precedent for microglia serving as a reservoir for virus in other models of virus-induced demyelination (Lipton, et al., 1995). Oligodendrocytes are readily identified as infected in MHV-infected rodents with either acute encephalitis or symptomatic, chronic demyelination because there is a large viral load under these conditions (Lampert, et al., 1973; Weiner, 1973; Sun, et al., 1995). However, in asymptomatic mice, in which virus load is low, the lack of reliable markers for oligodendrocytes makes determining whether this cell type is infected more difficult.

A summary of some features of commonly used MHV models of demyelination is shown in Table 1.

\section{PATHOLOGICAL CHANGES IN MHV-INFECTED RODENTS}

Although variations in virus and rodent strain used by different investigators studying JHMV-induced demyelination make a direct comparison of results difficult, several common themes emerge. First, virus persistence is a key element in the development of demyelination and, in general, the amount of demyelination and clinical disease appears to be proportional to the level of virus or its products. Demyelination could occur by one of several mechanisms. It could result from direct viral lysis of infected oligodendrocytes. Several early studies, based in part upon a lack of effect of immunosuppression on the disease process and in part on studies using electron microscopy, suggested that this mechanism was most important (Lampert, et al., 1973; Weiner, 1973). It is still believed that direct virus lysis of oligodendrocytes is important in mice with acute demyelination (Kyuwa and Stohlman, 1990). Another possibility is that demyelination results as a consequence of the immune response to the virus, either via direct cytolytic activity or as a consequence of cytokine activity. In support of this explanation, several more recent studies show that demyelination does not occur or occurs to a much lesser extent if mice are immunosuppressed prior to the initiation of the demyelinating process (Wang, et al., 1990; Houtman and Fleming, 1996). Alternatively, demyelination could result from an autoimmune response triggered by the initial viral infection. As mentioned above, there is evidence for the latter in rats infected with JHMV (Watanabe, et al., 1983) but this mechanism has not been identified thus far in infected mice. 
Table 1. Common models of MHV-induced neurological disease ${ }^{1}$

\begin{tabular}{|c|c|c|c|c|}
\hline Virus/strain & Persistence & Disease & Tropism & Comments \\
\hline${ }^{3} \mathrm{MHV}-3$ & yes & Vasculitis & $\begin{array}{l}\text { Ependyma, } \\
\text { Meninges }\end{array}$ & \\
\hline${ }^{4}$ MHV-A59 & yes & $\begin{array}{l}\text { Encephalitis } \\
\text { Hepatitis } \\
\text { Demyelination }\end{array}$ & $\begin{array}{l}\text { Neurons } \\
\text { Glia }\end{array}$ & Common cause of death is hepatitis \\
\hline${ }^{5}$ MHV-4 (JHM) & & Encephalitis & Glia & $\begin{array}{l}100 \% \text { mortality unless protected by } \\
\text { anti-viral antibody or } \mathrm{T} \text { cells }{ }^{2}\end{array}$ \\
\hline${ }^{6} \mathrm{JHM}-\mathrm{W}$ & yes & $\begin{array}{l}\text { Demyelination } \\
\text { Encephalitis }\end{array}$ & $\begin{array}{l}\text { Neurons } \\
\text { Glia }\end{array}$ & $\begin{array}{l}\text { Adopted by suckling mouse brain } \\
\text { passage }\end{array}$ \\
\hline${ }^{7} \mathrm{JHM}-\mathrm{DL}$ & ? & $\begin{array}{l}\text { Demyelination } \\
\text { Encephalitis }\end{array}$ & $\begin{array}{l}\text { Neurons } \\
\text { Glia }\end{array}$ & $\begin{array}{l}\text { Virulent large plaque variant from } \\
\text { JHM-W }\end{array}$ \\
\hline & & Demyelination & Neurons & \\
\hline${ }^{8} \mathrm{JHM} 2.2 \mathrm{v}-1$ & yes & Demyelination & Glia & $\mathrm{mAb}$ derived mutant \\
\hline${ }^{8} \mathrm{JHM} 2.2 / 7.2-\mathrm{v}-2$ & $?$ & $\begin{array}{l}\text { Minimal/No } \\
\text { Demyelination }\end{array}$ & Glia & Double mAb escape from $2.2 \mathrm{v}-1$ \\
\hline${ }^{7} \mathrm{JHM}-\mathrm{DM}$ & yes & $\begin{array}{l}\text { Encephalitis } \\
\text { Demyelination }\end{array}$ & $\begin{array}{l}\text { Astrocytes? } \\
\text { Glia } \\
\text { Neurons }\end{array}$ & Plaque variant of JHM-W \\
\hline${ }^{7} \mathrm{JHM}-\mathrm{DS}$ & yes & $\begin{array}{l}\text { Encephalitis } \\
\text { Demyelination }\end{array}$ & Glia & $\begin{array}{l}\text { Prominent demyelination } \\
\text { From JHM-W }\end{array}$ \\
\hline${ }^{9} \mathrm{JHM}-$ Wurzburg & yes & $\begin{array}{l}\text { Encephalitis } \\
\text { Demyelination }\end{array}$ & $\begin{array}{l}\text { Neurons } \\
\text { Glia }\end{array}$ & SDE in rats \\
\hline${ }^{10} \mathrm{JHM}-\mathrm{cl} 2$ & yes & $\begin{array}{l}\text { Encephalitis } \\
\text { Demyelination }\end{array}$ & $\begin{array}{l}\text { Glia } \\
\text { Neurons }\end{array}$ & Virulent variant similar to MHV-4 \\
\hline "JHM-X & yes & $\begin{array}{l}\text { Encephalitis } \\
\text { Demyelination }\end{array}$ & $\begin{array}{c}\text { Glia } \\
\text { From ATCC }\end{array}$ & Deletion in S protein \\
\hline${ }^{12} \mathrm{JHM}$ V5A13.1 & yes & $\begin{array}{l}\text { Encephalitis } \\
\text { Demyelination }\end{array}$ & $\begin{array}{l}\text { Glia } \\
\text { Neurons }\end{array}$ & mAb escape mutant \\
\hline${ }^{13} \mathrm{JHM}$ OBLV & no & Mild encephalitis & Olfactory neurons & \\
\hline${ }^{14} \mathrm{JHM}$ Ts8 & yes & Demyelination & Glia & $\begin{array}{l}\text { Prominent demyelination. Not readily } \\
\text { available }\end{array}$ \\
\hline
\end{tabular}

${ }^{1}$ Many ts mutants and recombinants available are not included in Table 1.

${ }^{2}$ Persistent infection and Demyelination in maternal antibody-protection model (Perlman, 1987).

${ }^{3}$ Tardieu, et al., 1986; ${ }^{4}$ Lavi, et al., $1984 ;{ }^{5}$ Cheever, et al., 1949; ${ }^{6}$ Weiner, $1973 ;{ }^{7}$ Stohlman, et al., $1982 ;{ }^{8}$ Fleming, et al., $1987 ;$

${ }^{9}$ Nagashima, et al., 1978; ${ }^{10}$ Taguchi, et al., 1985; ${ }^{11}$ Nakanaga, et al., 1986; ${ }^{12}$ Dalziel, et al., 1986; ${ }^{13}$ Pearce, et al., 1994; ${ }^{14} \mathrm{Haspel}$ et al., 1978.

A second major theme is that the same or similar pathological findings are present in all mice and rats with demyelination. In the earliest stages, viral antigen can be detected in the white matter with few histological changes observed. Soon thereafter, a large infiltration of lymphocytes and macrophages can be detected in areas of demyelination. The number of oligodendrocytes is decreased and the synthesis of mRNA specific for oligodendrocytes, such as myelin basic protein and proteolipid protein, is decreased at this time (Jordan, et al., 1989). Demyelination, with relative sparing of axons, occurs at this stage. Chemokines, particularly crg-2 and RANTES are expressed in areas of demyelination and attract lymphocytes ( $\mathrm{T}$ Lane and M. Buchmeier, personal communication). These lymphocytes, in turn, secrete cytokines that attract macrophages and activate microglia These areas of demyelination become larger and are dominated histologically by astrogliosis and the presence of a large number of lipid-laden macrophages. The activated astrocytes stain for several cytoki- 
nes and other immunomodulatory molecules, including TNF- $\alpha$, IL-6, IL-1ß and the inducible form of nitric oxide synthase (NOS2) but not for MHC class I or class II antigen (Sun, et al., 1995). The macrophages present in these lesions are also highly activated, but unlike monocytes in other pathological settings do not express high levels of cytokines. They do, however, express both MHC class I and class II antigens on their surface (Figure 1). At present, it is not known if macrophages attack only virus-infected cells or if uninfected cells (and associated myelin) are also damaged. In later stages, the demyelinating plaques become well demarcated. Cellular infiltrates resolve, although a few macrophages and astrocytes may still be present in these areas. Remyelination is sometimes observed. Virus is cleared and cellular debris removed. If virus has not continued to replicate, the animals recover clinical function. If virus is not controlled however, new areas of demyelination develop in other areas of the white matter. In areas that do not show remyelination, inactive plaques can be detected (Barac-Latas, et al., 1997).

\section{HOST IMMUNE RESPONSE TO JHMV AND MHV-A59}

\subsection{Humoral Response}

Since a key part of the above model is that incomplete clearance of MHV is necessary for demyelination to develop and since demyelination is in large part an immu-
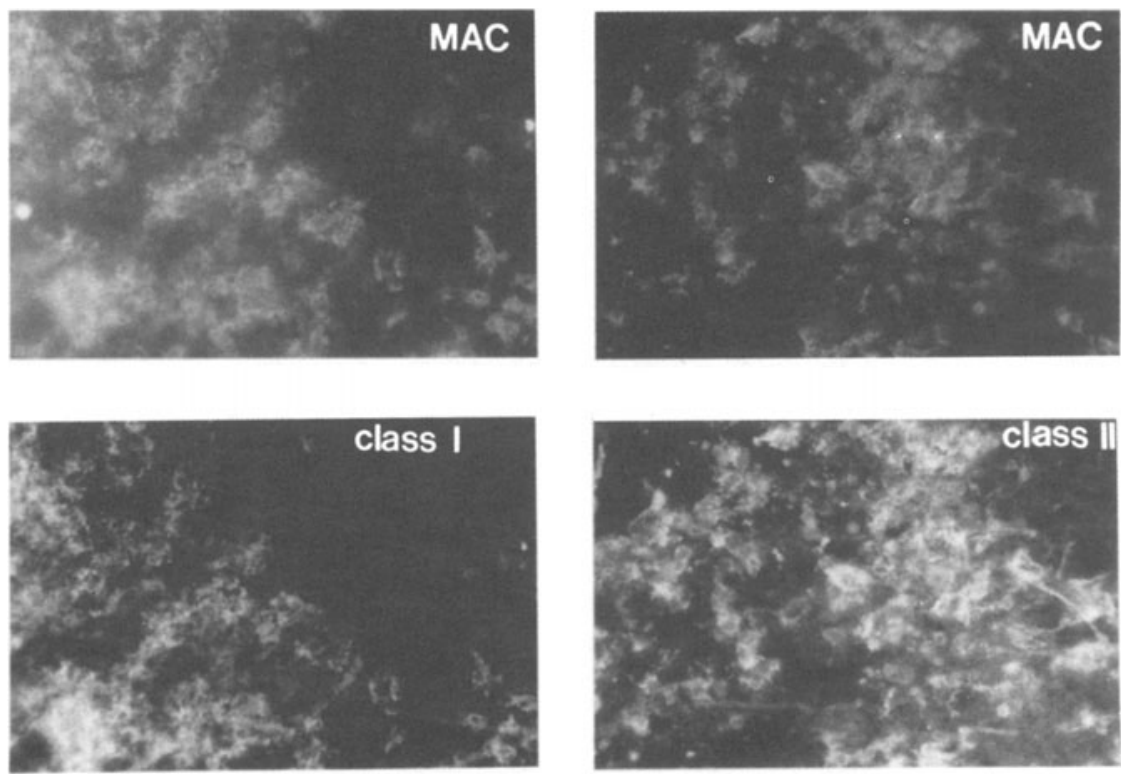

Figure 1. Macrophages/microglia express MHC class I and class II in mice persistently infected with JMHV. Suckling mice were infected with JHMV and nursed by dams previously immunized with live JHMV. The spinal cord was harvested from a mouse that developed hindlimb paralysis at 31 days p.i. Samples were simultaneously analyzed for expression of a macrophage marker (Mac-1) and MHC class I or class II antigen. FITC-conjugated goat anti-mouse antibody was used to detected MHC class I or class II antigen and Texas Red-conjugated goat-antirat antibody to detected Mac-1. 
nopathological phenomenon, an understanding of the immune response to MHV is important in delineating the details of these processes. Initial studies concentrated on the humoral response to MHV. The administration of neutralizing antibody prior to intracerebral infection with MHV prevents acute encephalitis by protecting neurons from infection but does not prevent demyelination (Buchmeier, et al., 1984). Other studies showed that neutralizing antibody was present in the blood and cerebrospinal fluid of mice and rats with demyelination (Stohlman and Weiner, 1981; Sorensen, et al., 1984; Dorries, et al., 1986; Jacobsen and Perlman, 1990). Thus, once demyelination is underway, neutralizing antibody is unable to prevent the process from continuing although it is able to protect neurons from infection. Consistent with this, Brown Norway rats develop an asymptomatic chronic demyelinating disease induced by JHMV and in these animals, high levels of antibody can be detected in the CNS. These antibodies may prevent most virus spread within the CNS and contribute to the mild nature of the disease (Watanabe, et al., 1987).

\subsection{Cell-Mediated Response}

Other studies showed the importance of CD4 and CD8 T cells in virus clearance. In experiments in which CD4 or CD8 T cells are depleted prior to infection with JHMV, the kinetics of virus clearance is delayed (Williamson and Stohlman, 1990; Pearce, et al., 1994). Similar results were obtained with mice in which CD4 or CD8 T cell function was genetically disrupted. In mice deficient in CD8 function ( $\left(32\right.$-microglobulin (-/-)), the $\mathrm{LD}_{50}$ for MHV-A59 is 0.001 that of normal mice (Gombold, et al., 1995).

Adoptive transfer experiments have also provided insight into the mechanisms of immune protection. Adoptive transfer of CD4 $\mathrm{T}$ cells prevented neuronal infection. In some cases, these cells also reduced virus replication and demyelination whereas in another report, virus replication and demyelination was not affected (Stohlman, et al., 1986; Körner, et al., 1991; Yamaguchi, et al., 1991). The difference in effect on virus replication may reflect differences in cytokine release or CD4 $\mathrm{T}$ cell cytotoxicity. The importance of CD8 $\mathrm{T}$ cells has also been shown in similar experiments. Adoptive transfer of CD8 T cells resulted in protection and enhanced virus clearance (Yamaguchi, et al., 1991; Stohlman, et al., 1995). In another set of experiments, rats immunized with recombinant vaccinia virus expressing the $\mathrm{S}$ protein were protected if exposed to virus 7 days after immunization; this is the time of maximal CD8 T cell response (Flory, et al., 1995). Interestingly, if rats were infected 21 days after immunization, they were not protected but rather became chronically infected with MHV. Since antibody can be detected at 21 days and not 7 days after immunization, these results are consistent with the idea, described above, that antibodies contribute to persistence and demyelination in these animals.

MHV-specific cytotoxic CD4 T cells may also have a role in virus clearance. No MHC class I-restricted CD8 T cells could be identified in mice infected with MHV-A59. However, MHC class II-restricted cytotoxic CD4 T cells could be identified in these animals. At present, it is not known if these cytotoxic T cells restricted by MHC class II antigen are uniquely important in mice with hepatitis or if they are generally important in MHV-infected mice (Heemskerk, et al., 1995).

In other studies, the CD8 and CD4 T cell epitopes recognized by JHMV-specific lymphocytes were identified. A summary of the epitopes identified thus far is shown in Table 2 . These epitopes have been identified using either splenocytes harvested from immunized mice and stimulated in vitro, $\mathrm{T}$ cell clones developed from the spleens and CNS or lymphocytes harvested from the CNS of mice acutely or persistently infected with MHV and analyzed in direct ex vivo cytotoxicity assays. In BALB/c mice, a CD8 T cell epitope 
Table 2. CD4 and CD8 T cell epitopes recognized in MHV-infected rodents

\begin{tabular}{lccc}
\hline Type of epitope & Source & $\begin{array}{c}\text { MHV } \\
\text { protein }\end{array}$ & Amino acids \\
\hline${ }^{1} \mathrm{CD} 8$ T cell & BALB/c mice & $\mathrm{N}$ & $318-326$ \\
${ }^{2.3} \mathrm{CD} 8 \mathrm{~T}$ cell & $\mathrm{C} 57 \mathrm{Bl} / 6$ mice & $\mathrm{S}$ & $510-518$ \\
${ }^{2} \mathrm{CD} 8$ T cell & $\mathrm{C} 57 \mathrm{Bl} / 6$ mice & $\mathrm{S}$ & $598-605$ \\
${ }^{4} \mathrm{CD} 4$ T cell & Lewis rat & $\mathrm{N}$ & $361-458$ \\
${ }^{5} \mathrm{CD} 4$ T cell & $\mathrm{C} 57 \mathrm{Bl} / 6$ mice & $\mathrm{M}$ & $128-147$ \\
${ }^{6.7} \mathrm{CD} 4$ T cell & $\mathrm{C} 57 \mathrm{Bl} / 6$ mice & $\mathrm{S}$ & $329-343$ \\
${ }^{6} \mathrm{CD} 4$ T cell & BALB $/ \mathrm{c}$ mice & $\mathrm{S}$ & $329-343$ \\
${ }^{8} \mathrm{CD} 4$ T cell & BALB $/ \mathrm{c}$ mice & $\mathrm{N}$ & $266-279$ \\
${ }^{7} \mathrm{CD} 4$ T cell & $\mathrm{C} 57 \mathrm{~B} 1 / 6$ mice & $\mathrm{S}$ & $358-372$ \\
& & $\mathrm{~S}$ & $408-422$ \\
\hline
\end{tabular}

${ }^{1}$ Bergmann, et al., 1993; ${ }^{2}$ Castro and Perlman, 1995; ${ }^{3}$ Bergmann, et al., 1996; ${ }^{4}$ Wege, et al., 1993; ${ }^{5}$ Xue, et al., $1995 ;{ }^{6}$ Heemskerk, et al., $1995 ;{ }^{7}$ Xue, S. and S.P., submitted for publication; ${ }^{8}$ Van der Veen, 1996.

encompassing amino acids 318-326 of the $\mathrm{N}$ protein is immunodominant, although there is evidence that other JHMV-specific CD8 T cell epitopes are recognized (Bergmann, et al., 1993; Stohlman, et al., 1993). These epitopes appear to be present within one or more nonstructural protein and have not been further characterized. In C57Bl $/ 6$ mice, two CD8 T cell epitopes (S-510-518 and S-598-605) are recognized (Castro and Perlman, 1995; Bergmann, et al., 1996). Both are located within a region of the S protein which is commonly deleted in many JHMV variants and during the course of persistence in C57Bl/6 mice (Parker, et al., 1989; Rowe, et al., 1997). Deletions and missense mutations in this region are not lethal for the virus but result in CTL escape in C57Bl/6 mice as described above. CD4 $\mathrm{T}$ cell epitopes have also been described in both strains of mice. In BALB/c mice, CD4 T cell epitopes are present within the $\mathrm{N}$ protein (Van der Veen, 1996) whereas in $\mathrm{C} 57 \mathrm{Bl} / 6$ mice such epitopes are located within the $\mathrm{S}$ and $\mathrm{M}$ but not the $\mathrm{N}$ proteins (Mobley, et al., 1992; Heemskerk, et al., 1995; Xue, et al., 1995). In no case are these epitopes located within the hypervariable region of the $\mathrm{S}$ protein and no mutations which result in escape from CD4 $\mathrm{T}$ cell surveillance have been identified.

\section{ROLE OF CYTOKINES}

Cytokines are likely to play a major role in MHV-induced demyelination but our understanding of this process is rudimentary. As in most acute encephalitides such cytokines as IL- $1 \alpha$, IL- $1 \beta$, TNF- $\alpha$, IL- 6 and IFN- $\gamma$ are detected in RNA samples harvested from the CNS of infected mice and with the exception of IFN- $\gamma$ are in part synthesized by resident CNS cells (Pearce, et al., 1994). IFN- $\gamma$ is produced by infiltrating immune cells and depletion of IFN- $\gamma$, either with neutralizing antibody or using mice in which the gene for IFN- $\gamma$ is disrupted leads to decreased virus clearance and greater mortality (Lane, et al., 1997). In contrast, neutralization of TNF- $\alpha$ did not appear to effect either the recruitment of T cells in the CNS, virus clearance or the development of demyelination (Stohlman, et al., 1995) and inhibition of NOS2 did not affect virus clearance (Lane, et al., 1997). Less is known about the role of cytokines in the chronic demyelinating process. The cytokines TNF- $\alpha$, IL-1 13 and IL-6 as well as NOS2 are expressed by astrocytes localized near to sites of demyelination in chronically infected spinal cords. These cytokines are synthesized for the 
most part by uninfected cells although infected astrocytes expressing these cytokines can occasionally be detected (Sun, et al., 1995). Some of these immunomodulatory molecules are directly toxic for oligodendrocytes or myelin and it will be important to determine the role of these cytokines in chronic demyelination.

\section{CONCLUSIONS}

Although progress has been made in understanding MHV persistence and the development of demyelination, much remains to be determined. The development of methods to genetically manipulate the MHV genome as well as the availability of mice in which the genes encoding one or more key immune functions are disrupted should facilitate progress in these areas. Several outstanding questions remain, including: 1) what enables virus to avoid clearance during the early stages of the infection? Virus is able to persist even if CTL escape mutants are not selected, albeit usually without the presence of infectious virus. 2) In what cells does virus persist, other than astrocytes, and what is the molecular form of the persistence? 3) What are the relative roles of virus, T cells, antibodies and cytokines in the demyelinating process? The answers to these questions will undoubtedly be complicated but the tools are available to start answering them.

\section{ACKNOWLEDGMENTS}

This research was supported in part by grants from the N.I.H. (NS24401, DC01711) and the National Multiple Sclerosis Society.

\section{REFERENCES}

Barac-Latas, V., Suchanek, G., Breitschopf, H., Stuehler, A., Wege, H., and Lassmann, H., 1997, Patterns of oligodendrocyte pathology in coronavirus-induced subacute demyelinating encephalomyelitis in the Lewis rat, Glia 19: 1-12.

Barnett, E. and Perlman, S., 1993, The olfactory nerve and not the trigeminal nerve is the major site of CNS entry for mouse hepatitis virus, strain JHM, Virology 194: 185-191.

Bergmann, C., McMillan, M., and Stohlman, S. A., 1993, Characterization of the Ld-restricted cytotoxic T-lymphocyte epitope in the mouse hepatitis virus nucleocapsid protein, J. Virol. 67: 7041-49.

Bergmann, C. C., Yao, Q., Lin, M., and Stohlman, S. A., 1996, The JHM strain of mouse hepatitis virus induces a spike protein-specific Db-restricted CTL response, J. Gen. Virol. 77: 315-325.

Buchmeier, M. J., Lewicki, H. A., Talbot, P. J., and Knobler, R. L., 1984, Murine hepatitis virus-4 (strain JHM)-induced neurologic disease is modulated in vivo by monoclonal antibody, Virology 132: 261-270.

Castro, R. F. and Perlman, S., 1995, CD8+ T cell epitopes within the surface glycoprotein of a neurotropic coronavirus and correlation with pathogenicity, J. Virol. 69: 8127-8131.

Cheever, F. S., Daniels, J. B., Pappenheimer, A. M., and Bailey, O. T., 1949, A murine virus (JHM) causing disseminated encephalomyelitis with extensive destruction of myelin, J. Exp. Med. 90: 181-194.

Chen, W. and Baric, R., 1996, Molecular anatomy of MHV persistence: coevolution of increased host resistance and virus virulence, J. Virol. 70: 3947-3960.

Dalziel, R. G., Lampert, P. W., Talbot, P. J., and Buchmeier, M. J., 1986, Site-specific alteration of murine hepatitis virus type 4 peplomer glycoprotein E2 results in reduced neurovirulence, J. Virol. 59: 463-471.

Dorries, R., Watanabe, R., Wege, H., and ter Meulen, V., 1986, Murine coronavirus-induced encephalomyelitides in rats: Analysis of immunoglobulins and virus-specific antibodies in serum and cerebrospinal fluid, $J$. Neuroimmunol. 12: 131-142.

Fleming, J. O., Trousdale, M. D., Bradbury, J., Stohlman, S. A., and Weiner, L. P., 1987, Experimental demyelination induced by coronavirus JHM (MHV-4): molecular identification of a viral determinant of paralytic disease, Microb. Pathog. 3: 9-20. 
Flory, E., Stuhler, A., Barac-Latas, V., Lassmann, H., and Wege, H., 1995, Coronavirus-induced encephalomyelitis: balance between protection and immunopathology depends on the immunization schedule with spike protein S, J. Gen. Virol. 76: 873-879.

Gombold, J., Sutherland, R., Lavi, E., Paterson, Y., and Weiss, S. R., 1995, Mouse hepatitis virus A59-induced demyelination can occur in the absence of CD8+ T cells, Microb. Pathog. 18: 211-221.

Haspel, M. V., Lampert, P. W., and Oldstone, M. B. A., 1978, Temperature-sensitive mutants of mouse hepatitis virus produce a high incidence of demyelination, Proc. Natl. Acad. Sci. USA 75: 4033-4036.

Heemskerk, M., Schoemaker, H., De Jong, I., Schijns, V., Spaan, W., and Boog, C. J. P., 1995, Differential activation of mouse hepatitis virus-specific CD4+ cytotoxic T cells is defined by peptide length, Immunology 85 : 517-522.

Heemskerk, M., Schoemaker, H., Spaan, W., and Boog, C., 1995, Predominance of MHC class II-restricted CD4+ cytotoxic T cells against mouse hepatitis virus A59, Immunology 84: 521-527.

Houtman, J. J. and Fleming, J. O., 1996, Dissociation of demyelination and viral clearance in congenitally immunodeficient mice infected with murine coronavirus JHM, J. Neurovirology 2: 101-110.

Jacobsen, G. and Perlman, S., 1990, Localization of virus and antibody response in mice infected persistently with MHV-JHM, Adv. Exp. Med. Biol. 276: 573-578.

Jordan, C., Friedrich, V., Godfraind, C., Caardellechio, C., Holmes, K., and Dubois-Dalcq, M., 1989, Expression of viral and myelin gene transcripts in a murine CNS demyelinating disease caused by a coronavirus, Glia 2: $318-329$.

Körner, H., Schliephake, A., Winter, J., Zimprich, F., Lassmann, H., Sedgwick, J., Siddell, S., and Wege, H., 1991, Nucleocapsid or spike protein-specific $\mathrm{CD}^{+} \mathrm{T}$ lymphocytes protect against coronavirus-induced encephalomyelitis in the absence of $\mathrm{CD}^{+} \mathrm{T}$ cells, J. Immunol. 147: 2317-2323.

Kyuwa, S. and Stohlman, S. A., 1990, Pathogenesis of a neurotropic murine coronvirus, strain JHM in the central nervous system of mice, Sem. Virol. 1, 273-280.

Lampert, P. W., Sims, J. K., and Kniazeff, A. J., 1973, Mechanism of demyelination in JHM virus encephalomyelitis, Acta Neuropathol. 24: 76-85.

Lane, T. E., Paoletti, A. D., and Buchmeier, M. J., 1997, Disassociation between the in vitro and in vivo effects of nitric oxide on a neurotropic murine coronavirus, J. Virol. 71: 2202-2210.

Lavi, E., Fishman, P. S., Highkin, M. K., and Weiss, S. R., 1988, Limbic encephalitis after inhalation of a murine coronavirus, Lab. Invest. 58: 31-36.

Lavi, E., Gilden, D., Highkin, M., and Weiss, S. R., 1986, The organ tropism of mouse hepatitis virus A59 in mice is dependent on dose and route of inoculation, Lab. Invest. 36: 130-135.

Lavi, E., Gilden, D., Wroblewska, Z., Rorke, L., and Weiss, S., 1984, Experimental demyelination produced by the A59 strain of MHV, Neurology 34: 597-603.

Lipton, H. L., Twaddle, G., and Jelachich, M. L., 1995, The predominant virus antigen burden is present in macrophages in Theiler's murine encephalomyelitis virus-induced demyelinating disease, J. Virol. 69: 2525-2533.

Mobley, J., Evans, G., Dailey, M. O., and Perlman, S., 1992, Immune response to a murine coronavirus: Identification of a homing receptor-negative $\mathrm{CD}^{+} \mathrm{T}$ cell subset that responds to viral glycoproteins, Virology 187 : 443-452.

Nagashima, K., Wege, H., Meyermann, R., and ter Meulen, V., 1978, Coronavirus induced subacute demyelinating encephalomyelitis in rats: A morphological analysis, Acta Neuropathol. 44: 63-70.

Nakanaga, K., Yamanouchi, K., and Fujiwara, K., 1986, Protective effect of monoclonal antibodies on lethal mouse hepatitis virus infection in mice, J. Virol. 59: 168-171.

Parker, S. E., Gallagher, T. M., and Buchmeier, M. J., 1989, Sequence analysis reveals extensive polymorphism and evidence of deletions within the E2 glycoprotein gene of several strains of murine hepatitis virus, $\mathrm{Vi}$ rology 173: 664-673.

Pearce, B. D., Hobbs, M. V., McGraw, T. S., and Buchmeier, M. J., 1994, Cytokine induction during T-cell-mediated clearance of mouse hepatitis virus from neurons in vivo, J. Virol. 68: 5483-5495.

Perlman, S. and Ries, D., 1987, The astrocyte is a target cell in mice persistently infected with mouse hepatitis virus, strain JHM, Microb. Pathog. 3: 309-314.

Perlman, S., Schelper, R., Bolger, E., and Ries, D., 1987, Late onset, symptomatic, demyelinating encephalomyelitis in mice infected with MHV-JHM in the presence of maternal antibody, Microb. Pathog. 2, 185-194.

Pewe, L., Wu, G., Barnett, E. M., Castro, R., and Perlman, S., 1996, Cytotoxic T cell-resistant variants are selected in a virus-induced demyelinating disease, Immunity $5: 253-262$.

Rowe, C. L., Baker, S. C., Nathan, M. J., and Fleming, J. O., 1997, Evolution of mouse hepatitis virus: Detection and characterization of S1 deletion variants during persistent infection, J. Virol. 71: 2959-2967.

Sorensen, O., Coulter-Mackie, M., Puchalski, S., and Dales, S., 1984, In vivo and in vitro model of demyelinating disease. IX. Progression of JHM virus infection in the central nervous system of the rat during overt and asymptomatic phases, Virology 137: 347-357. 
Sorensen, O., Perry, D., and Dales, S., 1980, In vivo and in vitro models of demyelinating diseases. III. JHM virus infection of rats, Arch. Neurol. 37: 478-484.

Stohlman, S. A., Bergmann, C. C., van der Veen, R. C., and Hinton, D. R., 1995, Mouse hepatitis virus-specific cytotoxic $\mathrm{T}$ lymphocytes protect from lethal infection without eliminating virus from the central nervous system, J. Virol. 69: 684-694.

Stohlman, S. A., Fleming, J. O., Brayton, P. R., Weiner, L. P., and Lai, M. M. C., 1982, Murine coronaviruses: isolation and characterization of two plaque morphology variants of the JHM neurotropic strain, J. Gen. Virol. 63: $265-275$.

Stohlman, S. A. and Frelinger, J. A., 1978, Resistance to fatal central nervous system disease by mouse hepatitis virus, strain JHM, Immunogenetics 6: 277-281.

Stohlman, S. A., Hinton, D. R., Cua, D., Dimacali, E., Sensintaffar, J., Hofman, F. M., Tahara, S. M., and Yao, Q., 1995 , Tumor necrosis factor expression during mouse hepatitis virus-induced demyelinating encephalomyelitis, J. Virol. 69: 5898-5903.

Stohlman, S. A., Kyuwa, S., Polo, J. M., Brady, D., Lai, M. M. C., and Bergmann, C. C., 1993, Characterization of mouse hepatitis virus-specific cytotoxic $\mathrm{T}$ cells derived from the central nervous system of mice infected with the JHM strain, J. Virol. 67: 7050-7059.

Stohlman, S. A., Matsushima, G. K., Casteel, N., and Weiner, L. P., 1986, In vivo effects of coronavirus-specific T cell clones: DTH inducer cells prevent a lethal infection but do not inhibit virus replication, J. Immunol. 136: 3052-3056.

Stohlman, S. A. and Weiner, L. P., 1981, Chronic central nervous system demyelination in mice after JHM virus infection, Neurology 31: 38-44.

Sun, N., Grzybicki, D., Castro, R., Murphy, S., and Perlman, S., 1995, Activation of astrocytes in the spinal cord of mice chronically infected with a neurotropic coronavirus, Virology 213: 482-493.

Taguchi, F., Siddell, S., Wege, H., and ter Meulen, V., 1985, Characterization of a variant virus selected inrat brains after infection by coronavirus MHV JHM, J. Virol. 54: 429-435.

Tardieu, M., Boespflug, O., and Barbe, T., 1986, Selective tropism of a neurotropic coronavirus for epndymal cells, neurons and meningeal cells, J.Virol. 60: 574-582.

Van der Veen, R. C., 1996, Immunogenicity of JHM virus proteins: Characterization of a CD4+ T cell epitope on nucleocapsid protein which induces different T-helper cell subsets, Virology 225: 339-346.

Wang, F., Stohlman, S. A., and Fleming, J. O., 1990, Demyelination induced by murine hepatitis virus JHM strain (MHV-4) is immunologically mediated, J. Neuroimmunol. 30: 31-41.

Watanabe, R., Wege, H., and ter Meulen, V., 1983, Adoptive transfer of EAE-like lesions from rats with coronavirus-induced demyelinating encephalomyelitis, Nature 305: 150-153.

Watanabe, R., Wege, H., and ter Meulen, V., 1987, Comparative analysis of coronavirus JHM-induced demyelinating encephalomyelitis in Lewis and Brown Norway rats, Lab. Invest. 57: 375-384.

Wege, H., Schliephake, A., Korner, H., Flory, E., and Wege, H., 1993, An immunodominant CD4+ T cell site on the nucleocapsid protein of murine coronavirus contributes to protection against encephalomyelitis, J. Gen. Virol. 74: 1287-1294.

Weiner, L. P., 1973, Pathogenesis of demyelination induced by a mouse hepatitis virus (JHM virus), Arch. Neurol. 28: $298-303$

Williams, R. K., Jiang, G., and Holmes, K. V., 1991, Receptor for mouse hepatitis virus is a member of the carcinoembryonic antigen family of glycoproteins, Proc. Natl. Acad. Sci. USA 88: 5533-5536.

Williamson, J. S. and Stohlman, S. A., 1990, Effective clearance of mouse hepatitis virus from the central nervous system requires both $\mathrm{CD}^{+}$and $\mathrm{CD} 8^{+} \mathrm{T}$ cells, $J$. Virol. 64: 4589-4592.

Xue, S., Jaszewski, A., and Perlman, S., 1995, Identification of a CD4+ T cell epitope within the M protein of a neurotropic coronavirus, Virology 208: 173-179.

Yamaguchi, K., Goto, N., Kyuwa, S., Hayami, M., and Toyoda, Y., 1991, Protection of mice from a lethal coronavirus infection in the central nervous system by adoptive transfer of virus-specific T cell clones, $J$. Neuroimmunol. 32: 1-9. 